\title{
Introduction. The fourth wave of feminism: From social networking and self-determination to sisterhood
}

\author{
OÑATI SOCIO-LEGAL SERIES VOLUME 10, ISSUE 1S (2020), 1S-9S: THE FOURTH WAVE OF FEMINISM: \\ FROM SOCIAL NETWORKING AND SELF-DETERMINATION TO SISTERHOOD \\ DOI LINK: HTTPS://DOI.ORG/10.35295/OSLS.IISL/0000-0000-0000-1160 \\ RECEIVED 23 DECEMBER 2020, ACCEPTED 23 DECEMBER 2020
}

\section{CATERINA PERONI* (iD) \\ LIDIA RODAK* (D)}

\section{Abstract}

This monographic issue aims at analysing, from different perspectives, the $4^{\text {th }}$ wave of feminism, in the frame of the rise of the new populism. Several issues characteristic of the second wave of feminism re-emerged during the contemporary worldwide mobilization of women: gender-based violence, abortion, sisterhood and self-determination. These topics, while characteristic of previous waves of feminism, are framed by the $4^{\text {th }}$ wave in the backlash against women's freedom and rights achieved in the last decades. The papers describe genealogies and changes in feminist repertoires, action and subjectivation: the emerging of "Hashtag Feminism" and the "call-out" culture focus on vulnerability as a socially shared condition, challenging the relationship with law and building new forms of recognition and solidarity between women. As a result, sisterhood came back to the discussion as an anti-essentialist bond based on trust and an expression of free will, with a potential of converting new mutual practices into common action.

\section{Key words}

$4^{\text {th }}$ wave of feminism; hashtag feminism; gender-based violence; abortion; sisterhood; populism

\footnotetext{
* Research fellow at the IRPPS-CNR ViVa project - Monitoring, Assessment and Analysis of the Measures to Prevent and Fight Violence against Women and coordinator of the module on Feminist Criminologies and intersectionalities of the Master in Critical Criminology at the University of Padua. Her main fields of research, teaching and study are the feminist studies in the field of gender-based violence, trafficking and prostitution, sexual and reproductive citizenship, discrimination of LGBTQI subjectivities included the criminal field, and of the production of discourses and practices of feminist and trans-feminist movements. Contact details: IRPPS - CNR, via Palestro 32, 00185 Rome (Italy). Email address: caterina.peroni@irpps.cnr.it * Lidia Rodak is adjunct at the Institute of Legal Science at the University of Silesia, coordinator of Legal Anthropology Research Group and the PI of the grant project Women's socio-legal justice. An analysis of circles of women by National Center of Science in Poland. Contact details: University of Silesia in Katowice, Faculty of Law and Administration, Institute of Legal Science, Bankowa 11, Katowice. Email address: lidia.rodak@us.edu.pl
} 


\section{Resumen}

Este número monográfico pretende analizar, desde diferentes perspectivas, la cuarta ola del feminismo, en el marco del ascenso del nuevo populismo. Varios temas característicos de la segunda ola del feminismo volvieron a emerger en la movilización global contemporánea de mujeres: violencia basada en el género, aborto, sororidad y autodeterminación. Dichos temas, siendo característicos de olas anteriores del feminismo, quedan enmarcados, en la cuarta ola, dentro del ataque a la libertad y los derechos de las mujeres, los cuales se lograron en pasadas décadas. Los artículos describen genealogías y cambios en los repertorios feministas, la acción y la subjetivación: la emergencia del "feminismo de etiqueta" y la "cultura de la señalación" se centran en la vulnerabilidad como condición socialmente compartida, cuestionando la relación con el derecho y construyendo nuevas formas de reconocimiento y solidaridad entre las mujeres. Como consecuencia, la sororidad volvió al centro del debate como un nexo antiesencialista basado en la confianza y la expresión del libre albedrío, con el potencial de convertir las nuevas prácticas mutuas en acción común.

\section{Palabras clave}

Cuarta ola del feminismo; feminismo de etiqueta; violencia basada en el género; aborto; sororidad; populismo 


\section{Table of contents}

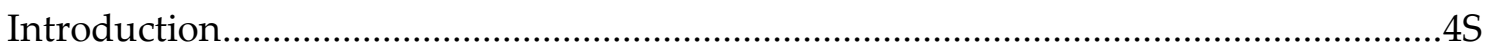

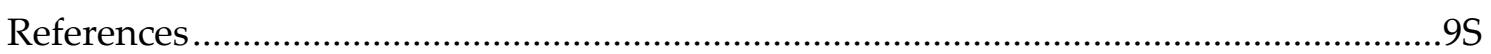




\section{Introduction}

This monographic issue contains papers presented during the workshop at the International Institute for the Sociology of Law (Oñati, Spain) coordinated by Caterina Peroni (National Research Council-Institute for Research on Population and Social Policies, Italy) and Lidia Rodak (University of Silesia, Poland) in May 2018.

The workshop aimed at analysing, from different perspectives and positioning, the fourth wave of feminism, in the frame of the rising of the new populism. During the workshop women from Italy, Poland, Spain, Sweden, Russia, Brazil and India investigated the reconceptualization of several issues characteristic of the second wave of feminism, which re-emerged during the contemporary worldwide mobilization of women: gender-based violence, abortion, sisterhood and self-determination. These topics, while characteristic of previous waves of feminism, remain important for the present activist movements on a global scale, so they constitute the $4^{\text {th }}$ wave. What was commented by the $4^{\text {th }}$ wave activists was: "I can't believe I still have to protest this shit again" (Kabus and Rodak 2020).

In the last decade, women's body has once again become the battleground for the redefinition of white and heterosexual identity and citizenship in western countries. From Latin America to Europe, the neo-fundamentalist attacks against so-called gender ideologies (Bellè et al. 2018), the renewed assault on the reproductive self-determination of women and the intensification of the public and political confrontation about the definition of status of sexual and gender-based violence in the contemporary neoliberal capitalism are framed by feminist scholars and activists as a hetero-patriarchal revenge against women's freedom and struggles for self-determination.

Indeed, contrary to the mainstream "liberal" discourse trivializing neoconservative sexual panics as "medieval" or "Taliban" (in any case othering it), feminists are well aware that they coherently belong to western modernity (Gelsthorpe and Morris 1990), which is founded on the heterosexual patriarchal norm and the construction of the (male and white) individual. The sexualization and reproductive exploitation of women's body is part of our story and re-emerges in its gendered violence, in particular, in times of economic restructuration, in order to confirm the centrality of the male heterosexual citizen, and, at the same time, to reaffirm the heterosexual norm and the centrality of heteronormative reproduction (Federici 2012, Zappino 2016, Bellè et al. 2018, Gago and Mason-Deese 2019).

Abortion and gender-based violence as attacks against women's sexual freedom and self-determination are in fact the main issues on which feminists had struggled during the so-called second wave of the movement. The backlash that followed and the renewed banning on abortion in several western countries show how the government of women's body is still central to the construction of the contemporary state, in its neoconservative and neoliberal expressions.

These elements constitute the field for the explosion of the rising of feminist movements in this fourth wave, which, from different contexts, identified and connected them as epiphenomena (of the violence) of the sexualized process of the restructuration of contemporary capitalism (Gago and Mason-Deese 2019), relegating women to the 
destiny of "mothers of the nation" (Hall 2019) and controlling their self-determination as a real backlash against the feminist achievements of the last decades.

What characterizes this new wave of feminist mobilizations worldwide is the global connection of this movement and its capacity for analytical, practical and symbolic elaboration, made possible thanks to the use of the web and, in particular, of social media by the new generations of women of all continents. It is known how these communication tools were, for example, the main channel of mobilization during the Arab Spring, and how girls in particular found there a space for communication and relationships capable of overcoming domestic walls and gender and national borders, sharing their experiences, reflections, problems, and ambitions with their peers all over the world (Munro 2013). The power and, above all, the material effects of the world campaign \#MeToo speak to us of a new space of communication and relationship that reconfigures the neutrality of the web as a place of anonymization, isolation and depersonalization, because they situate it in the context of a global movement that has been able to resignify it starting from the experience and positioning of millions of women.

In this sense, the communication space opened in the last decade by young bloggers and twitters constitutes what Munro has called "Hashtag Feminism", or feminism of the fourth wave, based on the "culture of call-out", which has been able to radically question the misogynist and sexist culture that pervades both public communication and the microphysics of everyday relationships in the experience of each one, in which the speech is immediately political and recognizable by all. Without ignoring the doubts raised by many parties, both internationally and locally, on the risks of prêt-à-porter justicialism, the emergence of a new form of Puritan moralism, and the risks of the raising of new forms of feminist punitivism, what emerges is the profound interconnection between the feminist political texture and its form of communication, the codes it uses and the relationships it manages to redevelop. In other words, of course, media is not neutral or neutralizable, but deeply situated in a field of conflict.

Hashtag feminism, with its intersectional, intergenerational, and transnational attitude, opened the way to a new questioning of the relationship with the law, the state, and citizenship rights. As the opposition to the ban on abortion mobilised women in Poland in order to prevent the approval of the prohibitionist bill and in South America women struggled to make the parliaments approve constitutional amendments and laws in favour of free reproductive choice for all women, the international strike radically questioned the sexual nature of the capitalistic exploitation of women, and the hashtag movements moved the risk of slipping into a punitive drift to the cultural, economic, social and political field, claiming self-defence and solidarity instead of the state's protection.

In this direction goes the paper of Martins, which analyses several hashtag campaigns launched since 2015 in Brazil against sexual harassment, gender-based violence, and the "naturalised representation of white masculinity" symbolised by the election of Bolsonaro in 2018. Martins, on one side, analyses the non-neutrality of the "call-out" feminist technopolitical mobilisations, which avoided the classical (feminist) criminological individualization of victimhood by focusing on vulnerability as a "socially shared condition" and constructing a collective conscience from a victim's 
perspective. Moreover, the campaigns aimed to overcome criminalization and the risk of a punitive drift, by creating connections between women and tools for mutualism, solidarity and trans-feminist alliances. These became the grounds for the massive movement \#EleNao against not only the election of Bolsonaro, but the neoliberal and heteropatriarchal violence he represent(ed).

Abortion and the neoconservative populist backlash against women's selfdetermination in Brazil are also the topics of De Nardin Budò, Rodrigues and Gindri, who analyse the political discourse of draft bills on abortion between the same timespan (2015-2018). The paper presents a qualitative systematic analysis of bills presented in one of the countries with more restrictive legislation on abortion. The discourse analysis shows the secular turn of contemporary neofundamentalist populism from the religious to the secular frame, rooted in alleged scientific arguments opposed to ideology -i.e. the notorious, "Gender" one (Kuhar and Patternotte 2017). In the Brazilian political discourse, this manipulation of science and modernity is declined in the application of individual human rights frame to the unborn child, in order to morally and legally criminalize abortion. According to the authors, the reasons of the prevalence of bill proposals criminalizing abortion can be interpreted as a demonstration of fear for women's free choice - therefore, we add, a backlash against women's freedom.

In the same directions goes the paper by Bielska-Brodziak, Drapalska-Grochowicz, Peroni and Rapetti on the counter-position of feminist movements and "anti-gender" forces in Poland and Italy concerning the right of abortion. Despite different political genealogies, these two countries share a strong influence of the Catholic church and the emergence in the last years of anti-gender, populist and neofundamentalist forces. The paper analyses the common framing of the repertoires of action of Polish and Italian anti-gender campaigns, focusing on the strategic use of human rights, law and science the three pillars of western modernity - in order to legitimate the attacks on women's self-determination. On the other side, their paper shows the global connection of women's movements facing the attempts to legally deny, in the case of Poland, or concretely prevent, in that of Italy, the right to abortion and, more in general, the sexist and moralist narrative sacralizing motherhood (Hall 2019). Feminist movements use online and offline mobilizations, massively flowing in the streets and, at the same time, using technopolitical tools, not only to return neo-fundamentalist discourses, but also to connect women, and build solidarity and new forms of mutualism and self-help. The authors argue that in these political practices it can be seen the seed of a new form of citizenship, intended as a political practice of rights and subjectivation.

The $4^{\text {th }}$ wave is primarily defined by its form, that is, by forms of interaction and contact among women, which mainly take place online (Rampton 2008). Social media and online groups, by facilitating the interaction among women, diversify the global feminist movement, creating hubs for women as "consciousness-raising groups" (Blevins 2018). Online and offline communication modes result in greater intensity of contacts, tightening of the ties among group members, and stronger and more effective forms of women's organization in the real world. This can be seen in all the examples analysed in the articles, from teenage relationships to interactions between feminist activists. As one can see, women organized in groups find the support they need and use the group for common goals. Additionally, interactions taking place in the groups create enclaves with 
higher awareness and readiness to express women's voice, to stand up or act together. Thanks to this, these "hubs" play the role of leading voices activating other people. The activity of such groups creates a transnational structure of feminist activism, going beyond local political or geographical conditions.

Although many topics of fundamental interest for the $4^{\text {th }}$ wave of feminism are not very different from the previous ones, this wave puts a special focus on the unsolved problems of inequality, of different forms of discrimination and violence, of women's individual autonomy and sisterhood itself. In addition, the $4^{\text {th }}$ wave of feminism includes the discussion of body positivity to empower men, women and transgender people, promoting the acceptance of all possible bodies. Such an anti-essentialist approach makes the $4^{\text {th }}$ wave of feminism open to the experiences of everybody.

Also, attention is addressed to the positive sides of femininity, and to the development of female consciousness, identity, and power, which is observed in this collection of papers as an emerging process of subjectivation and self-determination, stimulated by "hashtag feminism" and online communications.

These arguments make the $4^{\text {th }}$ wave of feminism a relevant framework to understand the current women's global mobilisation. Specifically, we argue that the global women's movement is addressing not only individual national or international issues, but is globally challenging the neoliberal paradigm of law and citizenship. Hence, this special issue contributes to describing different forms of women's resistance but also the creation of new forms and patterns of interactions, reformulating female alliances and relationships. This implies taking steps towards a new understanding of sisterhood, in contrast to what we know from previous discussions.

In fact, against the background of women's solidarity practices described in the articles in our collection, an interesting phenomenon emerged in the context of female sisterhood. The papers of Rodak and Mainardi analyse women's relationship and focus on the process of growing subjectivity, autonomy and self-determination of women not connected to feminist ideology, while Biglia considers women's relationship in the context of feminist activist groups.

The articles in the last section show how unevenly female support groups develop, both those related to the ideology of feminism and to the everyday relations between women and girls. One can see echoes of the $2^{\text {nd }}$ and $3^{\text {rd }}$ waves of feminism in a global level. Above all, however, there is a clear $2^{\text {nd }}$-wave type of interaction of women around a common defined goal, within both the activist groups and in the relationships among young girls, which involves a kind of alliance and complicity in the interactions.

This is demonstrated in the article entitled Mediated friendship: Online and offline alliances in girls' everyday lives in Italy, in which Mainardi analyses the topic of girl friendships, in the context of online and offline interactions. The research highlights the emergence of a new space for subjectivation that goes beyond heteronormative norms. Inspired by the freedom of online space through which female teenagers express their identity more freely and even play with it, they experience "performativity of gender". This analysis indicates that reshaping of female alliances, mainly based on complicity, can take place in this context. 
This can be read as evidence that women continue to work on the reparation of their relationships which are often dominated by low levels of mutual trust caused by the internalization of the patriarchal perspective, and on the individual process of subjectivation. Apparently, easy access to many groups (also online) changes the patterns of mutual interactions and facilitates seeing other women as they really are "with one's own eyes", not through "patriarchal glasses". This disenchantment also stimulates the process of increasing the individual autonomy of women.

The findings described in Rodak's paper contribute to discussion on sisterhood as follows. The research on special consciousness-raising groups of the circles of women in Poland indicates important changes in terms of the quality of sisterhood. In these groups, women draw their attention to the changing nature of mutual relations, which are contaminated by the sexism of internalized patriarchy. However, cultivating bonds and mutual support is, in their view, strongly determined by the development of individual autonomy and personal freedom. Practicing sisterhood is, one can say, a careful step towards other women, as an expression of empathy understood as a practice of one's own freedom. As such, it opens the doors for diversity and frees the discussion of sisterhood from the symbiosis called for by the $1^{\text {st }}$ wave of feminism.

In the fourth wave, different generations of activists converge who have gone through the last forty years of mobilizations, networks and movements often not communicating with each other and, indeed, in political, methodological and strategic conflict, reshaping in an extraordinarily new way the same practices and methodologies that were the subject of discord in new forms of recognition, alliance, and subjectivation. One of these is the question of separatism, which allowed the reopening of a profound reasoning on subjectivity and relationships, positioning the (various types of) privileges that cross the political spaces of the movement and of the groups that have converged, sometimes completely dissolving within it (and perhaps sometimes precisely because of this). Or the renewed need to build moments and spaces of self-awareness, starting from oneself, on sexuality, affections, ties and desires, often advanced by young and very young people with their specific scope, which is distinguished by the use of communication, and the different sense of community, of feminist relationship, of alliance. Barbara Biglia's paper focuses on these aspects, analysing the complicated relationship of feminist subjectivation and identity within generalist movements but also within feminist groups themselves, in terms of alliances (Butler 2015), sisterhood and hybridization. Biglia aims to answer the questions: "For a mobilization to take place, do we have to join together around identities? Do activists feel, in any way, united by a common way of being?", and, we would add, how can we define this commonality? According to Biglia, the networking politics with minorities and vulnerabilitysubjectivities is crucial in order to overcome identitarian positionings and resisting to the subsumbption of feminist struggles by the neoliberal declination of contemporary capitalism.

Hence, the sisterhood of the $4^{\text {th }}$ wave of feminism appears in its progressive version and can be understood only within an anti-essentialist approach, which welcomes diverse experiences of all individuals, and does not ask who the sister is, including also men. Sisterhood, in this perspective, can be defined as an honest mutual support based solely on empathy and understanding as an expression of free will, with a potential of 
converting this into common action. But this is a project for the future, which is hopefully a possible scenario that might materialize.

\section{References}

Bellè, E., Peroni, C., and Rapetti, E., 2018. One step up and two steps back? The Italian debate on secularization, heteronormativity and LGBTQI citizenship. Social Compass [online], 65(5), 591-607. Available from: https://doi.org/10.1177/0037768618800750 [Accessed 20 December 2020].

Blevins, K., 2018. bell hooks and Consciousness-Raising: Argument for a Fourth Wave of Feminism. In: J. Vickery and T. Everbach, eds., Mediating Misogyny. Cham: Palgrave Macmillan.

Butler, J., 2015. Notes toward a Performative Theory of Assembly. Cambridge, MA: Harvard University Press.

Federici, S., 2012. Revolution at Point Zero: Housework, Reproduction, and Feminist Struggle. Oakland: PM Press.

Gago, V., and Mason-Deese, L., 2019. Eight Theses on the Feminist Revolution. Toward Freedom [online], 10 September. Available from:

https://towardfreedom.org/story/eight-theses-on-the-feminist-revolution [Accessed 20 December 2020].

Gelsthorpe, L., and Morris, A., eds., 1990. Feminist Perspectives in Criminology. Buckingham: Open University Press.

Hall, B., 2019. Gendering resistance to right-wing populism: Black protest and a new wave of feminist activism in Poland? American behavioral scientist [online], 63(10), 1497-1515. Available from: https://doi.org/10.1177/0002764219831731 [Accessed 20 December 2020].

Kabus, N., and Rodak, L., 2020. Revolution is Woman. The case of Poland. Studi sulla Questione Criminale [online], 4 November. Available from:

https://studiquestionecriminale.wordpress.com/2020/11/04/revolution-is-womanthe-case-of-

poland/?fbclid=IwAR0jxSCFJF1t37OLIqqP6rftVkPE7K46Q nf_8U POnCX4Bsn40 d2OZv-jM [Accessed 20 December 2020].

Kuhar, R., and Paternotte, D., eds., 2017. Anti-Gender Campaigns in Europe Mobilizing against Equality. London/New York: Rowman and Littlefield.

Munro, E., 2013. Feminism: A Fourth Wave? Political Insight [online], 4(2), 22-25. Available from: https://doi.org/10.1111/2041-9066.12021 [Accessed 20 December 2020].

Rampton, M., 2008. Four Waves of Feminism. Pacific Magazine [online], Fall. Available from (reprint): http://www.pacificu.edu/about-us/news-events/four-wavesfeminism [Accessed 20 December 2020].

Zappino, F., ed., 2016. Il genere tra neoliberismo e neofondamentalismo. Verona: Ombre Corte. 